\title{
Electrical muscle stimulation mobilizes endothelial progenitor cells in ICU patients
}

\author{
C Stefanou ${ }^{1 *}$, G Mitsiou ${ }^{1}$, E Karatzanos ${ }^{1}$, K Psarra² ${ }^{2}$ E Angelopoulos ${ }^{1}$, S Dimopoulos ${ }^{1}$, V Gerovasili ${ }^{1}$, I Vasileiadis ${ }^{3}$, \\ C Routsi ${ }^{1}$, S Nanas ${ }^{1}$ \\ From ESICM LIVES 2015 \\ Berlin, Germany. 3-7 October 2015
}

\section{Intr}

In the critically ill, the number of the bone marrowderived endothelial progenitor cells (EPCs) in peripheral blood constitutes a regeneration index of the endothelium of tissues that suffered the consequences of critical illness. Furthermore, electrical muscle stimulation (EMS) has been shown to induce beneficial effects in relation to prevention of acquired muscle weakness and atrophy, as well as weaning duration. The acute effects of EMS on EPCs have been scantily explored.

\section{Objectives}

Our hypothesis was that EMS, an exercise equivalent, increases EPCs in ICU patients.

\section{Methods}

Sample was consisted of 32 mechanically ventilated (for $>72 \mathrm{hrs}$ ) septic patients of a multidisciplinary ICU, aged (mean \pm SD) $58 \pm 14$ yrs. Ten patients were on steroids (group S), while 22 patients were not (group A) (APACHE-II score: $21.5 \pm 8.7$ vs $19.6 \pm 7.2$ respectively). Patients were randomized to one of two 30 min EMS biphasic protocols (PR1: $75 \mathrm{~Hz}, 400 \mu \mathrm{sec}, 6 \mathrm{~s}$ on - 21s off, PR2: $45 \mathrm{~Hz}, 400 \mu \mathrm{sec}, 5 \mathrm{~s}$ on - 12s off). Blood was sampled before and immediately after the EMS implementation. EPCs were quantified by flow cytometry, utilizing the surface markers CD34, CD133, CD45; for the mature circulating endothelial cells (CECs, indices of endothelial injury), CD34, CD45, VEGFR 2 were utilized.

\section{Results}

In all patients, EPCs (cells / million enucleated, mean \pm SE) increased from $13.53 \pm 1.80$ to $20.81 \pm 2.99$ ( $\mathrm{p}=0.013)$.

${ }^{1}$ National and Kapodistrian University of Athens, First Critical Care Departement, Athens, Greece

Full list of author information is available at the end of the article
Group S demonstrated a different response from group A $(\mathrm{p}=0.015)$. In group A, EPCs increased from $12.09 \pm 2.27$ to $23.82 \pm 4.05(\mathrm{p}=0.002)$. In group $\mathrm{S}$, EPCs did not change (from $16.70 \pm 2.79$ to $14.20 \pm 2.69, \mathrm{p}=0.46$ ). PR1 did not differ from PR2 ( $p=0.60$ in whole cohort, $p=0.67$ in group $\mathrm{S}, \mathrm{p}=0.84$ in group $\mathrm{A})$. No correlation among the EPCs increase and the contraction force $(r=0.24$, $\mathrm{p}=0.28)$ or maximal current $(\mathrm{r}=0.12, \mathrm{p}=0.64)$ was observed. Furthermore, in all patients CECs increased from $16.50 \pm 2.57$ to $23.84 \pm 3.40(\mathrm{p}=0.008)$. No difference between the groups $A$ and $S(p=0.21)$ or the EMS protocols PR1 and PR2 ( $p=0.20)$ was found. During EMS, no side effects, ECG or haemodynamic complications were observed.

\section{Conclusions}

The present study showed that the number of EPCs and CECs increases after EMS implementation in septic, critically ill patients. No difference was established between the two EMS protocols. Steroids, likely because they are marrow suppressants, seem to inhibit EPCs. EMS may act beneficially by mobilizing EPCs, in the same direction as exercise. Further investigation is required to explore the underlying pathophysiological mechanism.

\section{Authors' details \\ Published: 1 October 2015 \\ References
1. Cribbs, et al: Intensive Care Med 2012, 38:429-36.
2. Routsi, et al: Critical Care 2010, 14:R74.}

${ }^{1}$ National and Kapodistrian University of Athens, First Critical Care

Departement, Athens, Greece. 'Evangelismos General Hospital, ImmunologyHistocompatibility, Athens, Greece. ${ }^{3}$ National and Kapodistrian University of Athens, First Department of Respiratory Medicine, Athens Greece. 
doi:10.1186/2197-425X-3-S1-A207

Cite this article as: Stefanou et al.: Electrical muscle stimulation

mobilizes endothelial progenitor cells in ICU patients. Intensive Care

Medicine Experimental 2015 3(Suppl 1):A207.

\section{Submit your manuscript to a SpringerOpen ${ }^{\mathcal{O}}$ journal and benefit from:}

- Convenient online submission

- Rigorous peer review

- Immediate publication on acceptance

- Open access: articles freely available online

- High visibility within the field

- Retaining the copyright to your article

Submit your next manuscript at $\gg$ springeropen.com 